\title{
Lietuvos ūkininkų ūkių ekonominio gyvybingumo palyginamoji analizè
}

\section{Nelè Jurkẻnaitè}

Lietuvos agrarines ekonomikos institutas, V. Kudirkos g. 18-2, LT-03105, Vilnius

El.paštas: nele@laei.lt
Straipsnyje pateiktas tyrimas žemès ūkio gyvybingumo tematika papildo ankstesnius mokslininkų darbus, nagrinėjančius labai svarbų ekonominio gyvybingumo aspektą. Mokslinès literatūros ir dokumentų turinio analizė, mokslininkų požiūriu ir interpretacijų sintezė leido išskirti pagrindines ekonominio gyvybingumo tyrimų kryptis ir jų ribotumus bei parinkti rodiklius ūkininkų ūkių trumpalaikio ir ilgalaikio ekonominio gyvybingumo situacijos analizei. Remiantis parinktais vertinimo kriterijais ištirtas Lietuvos javų, rapsų, augalininkystės, pienininkystės bei augalininkystės-žolèdžių gyvulių ūkininkavimo tipų ūkininkų ūkių ekonominio gyvybingumo pokytis. Lyginamoji analizė atlikta remiantis 2004 ir $2010 \mathrm{~m}$. ùkių apskaitos duomenų tinklo respondentinių ūkininkų ūkių situacija. Tyrimas parodè, kad ūkių ekonominis gyvybingumas sumažèjo. Ūkininkų ūkių, nepajègiančių padengti gamybinių išlaidų arba bendrųjų išlaidų, šiek tiek padaugëjo, tačiau reikšmingai sumažějo ilgalaikis ekonominis žemès ūkio veiklos patrauklumas.

Raktažodžiai: žemès ūkis, ūkininko ūkis, gyvybingumas

\section{IVADAS}

Gyvybingumo problematiką nagrinèja ìvairių mokslo sričių tyrejjai. Biologijos mokslo pasiekimai sprendžiant augalų ir gyvūnų rūšių gyvybingumo problemas padeda ịveikti apsirūpinimo maistu ir biologinès įvairovès išsaugojimo iššū kius, didina ūkininkavimo veiklos patrauklumą. Pastaruoju metu įvairių mokslo krypčių tyrèjų dèmesi patraukè gyvybingumo teorija (Aubin, 1991; Aubin et al., 2011), kuri nagrineja sudètingų sistemų evoliuciją. Šios teorijos šalininkai siūlo matematinius metodus, padedančius tirti sistemų ir jų tinklų evoliuciją ir leidžiančius identifikuoti negyvybingo vystymosi tendencijas bei pritaikyti kontrolès mechanizmą, būtiną sistemos gyvybingumui palaikyti. Pvz., S. Baumgärtner, M. F. Quaas (2009) analizuoja ekologinį-ekonomini gyvybingumą, P. Huck (2007) pasitelkia gyvybingumo teoriją, siekdamas įvertinti bendrosios žemès ūkio politikos poveikị ilgalaikiam žemès ūkio paskirties žemès derlingumui išsaugoti. Gyvybingumo teorijos taikymas žemès ūkyje leidžia pagerinti sprendimų priemimą ir suteikia vertingų ižvvalgų, tačiau praktikoje pasiekti gerų rezultatų trukdo valdymo tikslų prieštaringumas ir nepakankamas aplinkos veiksnių poveikio vertinimas.

Žemès ūkio gyvybingumas gali būti tiriamas laikantis darnios plètros požiūrio išskiriant ekonominę, socialinę ir aplinkosauginę dimensijas. Toks požiūris leidžia nustatyti svarbiausius rodiklius, susijusius su žemès ūkio sistemos gyvybingumu reaguojant ì išteklių trūkumo, aplinkos pokyčių problemas ir pan. Parinktų rodiklių minimalių reikalavimų laikymasis leis palaikyti tam tikrų subsistemų gyvybingumą, kad jos neišnyktų ar kuo ilgiau būtų išsaugotos. Žemès ūkio gyvybingumo darnios plètros problematika buvo nagrinèjama JAV (CAST, 1998) ir Kanadoje (Scott, 2005; Scott, 2008; Scott, Colman, 2008; Scott, Colman, 2008a), tačiau Europos Sąjungoje toks požiūris ị gyvybingumą susilaukè mažiau tyrejų dèmesio. Net Europos Komisija, apibrěždama ūkių gyvybingumą, akcentuoja ekonominę ir socialinę dimensiją (nors pripažistama ir ekologinès dimensijos svarba) (A Framework.., 2001). 
Straipsnyje ūkininkų ūkių gyvybingumas nagrinėjamas siaurąa prasme pasirenkant analizei ekonomini aspektą, kuris dèl svarbos žemès ūkio sistemai neretai tapatinamas su gyvybingumo samprata. Žemès ūkio ekonominio gyvybingumo problematika susilaukè daugelio tyrejų dèmesio: siūlomi vertinimo kriterijai, kurie leidžia tirti gyvybingumo situaciją ìvairiais požiūriais (Zeddies, 1991; Morehart, 2000; A Framework..., 2001; Foltz, 2004; Scott, 2005; Glauben et al., 2006; Scott, Colman, 2008; Scott, Colman, 2008a; Connolly, 2009; Dillon et al., 2009; Developments..., 2010; EU..., 2010; Fritzsch et al., 2010; Vrolijk et al., 2010; Agrosynergie, 2011; Savickienè, Slavickienè, 2012). Straipsnyje ekonominio gyvybingumo pokyčiui tirti pasitelkiami ne tradiciniai tyrejų taikomi kriterijai su empiriškai nustatytomis ekonominio gyvybingumo ribomis, o ilgalaikio ir trumpalaikio gyvybingumo sampratos. Pateiktas tyrimas padeda geriau suvokti mažai tirtą Lietuvos žemès ūkio gyvybingumo problematiką ir papildo jau atliktus darbus nagrinejjant šalies ūkininkų ūkių gyvybingumą kitu aspektu.

Tyrimo objektas - ūkininkų ūkių ekonominis gyvybingumas.

Tyrimo tikslas - išanalizavus pagrindines ekonominio gyvybingumo tyrimų kryptis, parinkti vertinimo kriterijus ir ištirti javų, rapsų, augalininkystès, pienininkystès bei augalininkystės-žolèdžių gyvulių ūkininkavimo tipų ūkininkų ūkių ekonominio gyvybingumo pokyti Lietuvoje.

Ekonominio gyvybingumo vertinimo kriteriju identifikavimas atliktas remiantis mokslinès literatūros ir dokumentų turinio analize, mokslininku požiūrių ir interpretacijų sinteze. 2004 ir 2010 m. pasirinktų analizei ūkininkavimo tipų ūkininkų ūkių ekonominio gyvybingumo situacijos lyginamoji analizè atlikta remiantis straipsnyje aprašyta tyrimo metodika.

\section{TYRIMŲ METODAI IR SĄLYGOS}

Ekonominio gyvybingumo vertinimas žemès ūkyje. H. Bossel (2001) nusako gyvybingumą, kaip sistemos gebejimą išgyventi ir vystytis, bei siūlo taikyti sisteminị požiūrị i gyvybingumą akcentuojant subsistemų funkcionavimo svarbą visos sistemos gyvybingumui. Šis požiūris skatina didelę tyrimų įvairovę. Tyrimų krypties išeities taškas yra gyvybingumo apibrèžimas. Tyrèjai neretai su- siaurina gyvybingumo sampratą iki ekonominio arba finansinio aspektų, o šios sampratos dažnai suvokiamos kaip sinonimai. Tačiau nors šie aspektai nèra tapatūs, finansinès analizès rezultatai papildo ekonominę analizę ir leidžia geriau suvokti gyvybingumo problematiką bei priimti geresnius sprendimus.

Svarbus ekonominio gyvybingumo tyrimo atspirties taškas - išskirti trumpalaiki ir ilgalaiki gyvybingumą. M. Morehart (2000) sieja ūkininkų ūkių finansini gyvybingumą su trumpalaike perspektyva ir siūlo gyvybingų ùkių požymiu laikyti gamybinių išlaidų padengimą iš pajamų už parduotą produkciją. J. Zeddies (1991) apibrèžia trumpalaiki gyvybingumą kaip ūkininko ūkio gaminamos produkcijos kiekio ir kainos bei jai pagaminti panaudotų išteklių ir valstybinès paramos gamybai (taip pat ir taikomų ribojimų) skirtumą.

Trumpalaikio gyvybingumo analizè leidžia laiku pastebėti neigiamas tendencijas žemès ūkyje. Ypač informatyvus analizès elementas yra pajamų (arba îplaukų) ir veiklos išlaidų struktūros tyrimas (Scott, Colman, 2008; Developments..., 2010; EU..., 2010), kuris atskleidžia ir ūkininko ūkio veiklos, ir ịvairių ūkininkavimo tipų gilumines problemas, leidžia laiku pastebėti pokyčius žemès ūkio sektoriuje. Jeigu ūkininko ūkio pajamos nepadengia gamybinių išlaidų, ùkis yra negyvybingas ir veikla turi būti nutraukiama. Tačiau praktikoje dažnai ūkio su neigiamais veiklos rezultatais savininkas ir toliau ùkininkauja. M. Morehart (2000) teigia, kad ūkininko ūkis gali išgyventi metus, jeigu padengiamos kintamosios išlaidos, ir net kelerius metus, jeigu jis sugeba iš kitų šaltinių pritraukti lèšu savo poreikiams tenkinti. Galutinis sprendimas dèl veiklos nutraukimo priklausys nuo subjektyviu ir objektyvių priežasčių: ūkininko lūkesčių dèl kitų metų verslo rezultatų ir jo poreikių; galimybès pritraukti lěšu iš šaltinių, nesusijusių su žemės ūkio veikla; ūkininko gebejjimų, kurie gali būti parduoti kitam darbdaviui arba panaudoti pradedant pelningesni verslą, nesusijusį su žemès ūkiu, ir pan.

Išsami namų ùkio pajamų (arba ịplaukų) struktūros analizè padètų geriau suprasti ūkininko motyvaciją toliau ūkininkauti ir tiksliau prognozuoti sektoriaus gyvybingumą ateityje. Tačiau ūkininkų ūkių pajamu struktūra dažnai tiriama remiantis ūkių apskaitos duomenų tinklo (ŪADT) metodika, kuri rodo ribotą ekonominio gyvybingumo vaizdą, nes kaupia duomenis tik apie pajamas už parduotą 
žemès ùkio produkciją ir kitą ūkinę veiklą. Ši Europos Komisijos taikomos metodikos tyrimų krypties ribotumą pastebèję tyrèjai atliko išsamesnes studijas šeimos ūkio lygmeniu, tačiau dèl duomenų stokos tokie darbai apima tik pasirinktas šalis, todèl dažnai pasižymi mažesne tyrimo imtimi ir patikimumu (Hennessy, O’Brien et al., 2007; Fritzsch et al., 2010). Lietuvos ŪADT tyrimo duomenys leidžia papildomai matyti ūkininko pajamas iš ne žemès ūkio veiklos, t. y. galima atlikti išsamesnę ekonominio gyvybingumo analizę namų ūkio lygmeniu.

Žemès ùkio sektoriaus ekonominio gyvybingumo tendencijas rodo ūkio grynosios pridètinès vertès (ŪGPV) arba jos dalies, tenkančios vienam sąlyginiam darbuotojui (A Framework..., 2001; EU..., 2010; Developments..., 2010; Agrosynergie, 2011), bei bendrojo ūkio pelno su subsidijomis (BŪPS) pokyčiai (Scott, Colman, 2008). Šie rodikliai leidžia matyti ūkininko ūkio gamybos išlaidų prigimtị, išsiaiškinti, kiek prie ùkio gyvybingumo užtikrinimo prisideda šeimos ištekliai (ŪGPV) ir iš išorès pritraukti ištekliai (BŪPS). Iš esmès einamųjų metų rodikliai rodo trumpalaikị ekonominị gyvybingumą, o jų tendencijų analizè suteikia naudingų izžvalgų dèl ūkio gyvybingumo ateityje. Neigiamas ŪGPV rodiklis reiškia, kad ūkio savininkas nesugeba padengti gamybinių išlaidų, todèl gali būti priimtas sprendimas nutraukti šią veiklą. BŪPS rodiklis rodo, ar padengiamos bendrosios gamybos išlaidos.

Europos Komisija apibrežia ūkių gyvybingumą per ekonominę dimensiją ir sieja ji su galimybe generuoti pakankamai lèšu, reikalingų gamybai išsaugoti, pabrèžiant ilgalaikę ūkininko ūkio ekonominio gyvybingumo perspektyvą. Remiantis J. Zeddies (1991) ir M. Morehart (2000) siūlomais apibrèžimais, trumpalaikejje perspektyvoje gyvybingas ūkis generuoja pakankamai pajamų bendrosioms gamybos išlaidoms padengti, tačiau šis aspektas nesusijęs su adekvačiu atlyginimu už ūkininko ir jo ūkio narių darbą. Ilgalaiki gyvybingumą siūloma analizuoti pagal ekonominio pelno rodiklį siekiant ịvertinti, ar ūkininkas gauna pakankamą atlyginimą už bendrąsias išlaidas ir neatlyginamų išteklių naudojimą žemès ūkyje, palyginti su kitais verslais (Zeddies, 1991; Developments..., 2010; EU..., 2010; Vrolijk et al., 2010; Agrosynergie, 2011). Nustatant negyvybingą ūkio būseną siūloma vadovautis neigiamu ekonominiu ūkio pelnu su subsidijomis (EÜPS), kuris siejamas su ūkininko sprendimu perkelti savo išteklius $\mathfrak{i}$ kitą šaką. Rodiklio tendencijos įvairių ūkininkavimo tipų ūkiuose arba sektoriuje rodo, kaip keičiasi pasirinktos ūkininkavimo veiklos patrauklumas, palyginti su kitomis verslo alternatyvomis. Ekonominio gyvybingumo tendencijos gali būti nustatomos tiriant ūkininko ūkio, ūkininkavimo tipo ūkių arba sektoriaus pajamų (arba ịplaukų) ir ekonominių išlaidų struktūrą (Developments..., 2010; EU..., 2010).

Vertinant ekonomini gyvybingumą tyrejjai siūlo papildomai analizuoti finansinius rodiklius, kurie suteikia daugiau informacijos apie ūkininkų ūkių gyvybingumą. Pvz., J. Zeddies (1991), J. Scott ir R. Colman (2008), EU... (2010) siūlo nustatyti mokumo rodiklį, Agrosynergie (2011) bei J. Scott ir R. Colman (2008) - investicijų grąžos rodiklį, Agrosynergie (2011) - turto grąžos rodiklị ir pan. Finansinių rodiklių analizè leidžia atskleisti probleminius aspektus, kuriuos lemia ūkininkų ūkio išlaidų bei nuosavybès struktūros ypatumai. Šie rodikliai gali būti papildomai naudojami nustatant ūkininkų ùkių ekonominio gyvybingumo slenkstị pagal ekonominio dydžio klasę, nes jie leidžia matyti situaciją kompleksiškai ir įvertinti svarbiausius ekonominio gyvybingumo aspektus. Tyrimas neapima minètu rodiklių analizès, nes 2010 ir $2004 \mathrm{~m}$. ūkių ekonominio dydžio intervalai yra nepalyginami.

Apibendrinant galima teigti, kad tyrèjai išskiria trumpalaikio ir ilgalaikio ekonominio gyvybingumo sampratas. Trumpalaikis ekonominis gyvybingumas, savo ruožtu, nagrinėjamas pabrèžiant du esminius aspektus: šeimos išteklius ir iš išorès pritrauktus išteklius. Ilgalaikio gyvybingumo samprata siejama su veiklos ekonominiu patrauklumu, palyginti su kitomis alternatyvomis.

Esminis trumpalaikio ir ilgalaikio ekonominio gyvybingumo skirtumas pasireiškia išlaidomis. Remiantis mokslinès literatūros analize galima teigti, kad trumpalaikis gyvybingumas sietinas su ùkio galimybe padengti gamybines arba bendrąsias išlaidas, o ilgalaikis - su ekonominemis išlaidomis. Šis aspektas laikomas tyrimo atspirties tašku darant prielaidą, kad teigiama arba lygi nuliui rodiklio reikšmé rodo ūkininko ūkio gyvybingumą pagal pasirinktą analizei kriterijų. Pažymètina, kad tas pats ūkis gali būti gyvybingas trumpalaikèje perspektyvoje, tačiau negyvybingas - ilgalaikeje.

Tyrimo metodika. Lietuvos ūkininku ūkių ekonominio gyvybingumo pokyčio analizei buvo 
parinkti 2004 ir 2010 m. Tai leidžia palyginti gyvybingumo situacijos pokyti po įstojimo i ES. Pokytis tiriamas analizuojant keturių ūkininkavimo tipų ūkininkų ūkius: javų ir rapsų, augalininkystès, pienininkystès ir augalininkystès-žolèdžių gyvulių. Žemès ūkio surašymo duomenimis, šių ūkininkavimo tipų ūkiai 2003 m. sudare 56,5\%, o 2010 m. - 64,5\% šalies prekinių ūkininkų ūkių. $2004 \mathrm{~m}$. tyrimas remiasi $1028,2010 \mathrm{~m}$. - 1039 respondentinių ūkininkų ūkių veiklos rezultatais.

Ūkininkų ūkių ekonominio gyvybingumo pokyčio analizei parinkti trys rodikliai - ŪGPV,
BŪPS ir EŪPS (1 lentelè), kurie atskleidžia svarbius trumpalaikio ir ilgalaikio ekonominio gyvybingumo aspektus bei îvertina ùkių galimybę padengti skirtingos prigimties išlaidas.

Kiekvieno respondentinio ūkininko ūkio ekonominis gyvybingumas buvo analizuojamas atsižvelgiant $\mathfrak{i}$ visas ūkyje vykdomas veiklas. Pajamos ir bendrosios išlaidos ívertinamos remiantis ŪADT ūkių duomenimis. Išlaidos apskaičiuojamos remiantis šiomis prielaidomis:

1. Ūkininko ir jo ūkio narių neapmokèto darbo išlaidos apskaičiuojamos dauginant metines visų

\section{1 lentelè. Tyrimo rodiklių struktūra}

Table 1. Structure of research criteria

\begin{tabular}{|c|c|c|c|c|c|c|}
\hline & & & & \\
\hline & & & & $\begin{array}{l}\text { Ūkio grynoji } \\
\text { pridètinè vertè } \\
\quad(\overline{U G P V}) \\
\text { Farm net value } \\
\text { added (FNVA) }\end{array}$ & $\begin{array}{c}\text { Bendrasis } \\
\text { ūkio pelnas su } \\
\text { subsidijomis } \\
\text { (BŪPS) } \\
\text { Farm net } \\
\text { income (FNI) }\end{array}$ & $\begin{array}{l}\text { Ekonominis ūkio } \\
\text { pelnas su subsidi- } \\
\text { jomis (EŪPS) } \\
\text { Economic profit } \\
\text { (EP) }\end{array}$ \\
\hline \multirow{4}{*}{ 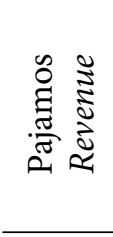 } & \multicolumn{3}{|c|}{ Bendroji produkcija / Total output } & + & + & + \\
\hline & \multicolumn{3}{|c|}{ Gamybos subsidijos / Subsidies } & + & + & + \\
\hline & \multicolumn{3}{|c|}{$\begin{array}{l}\text { Parama investicijoms } \\
\text { Subsidies on investments }\end{array}$} & & + & + \\
\hline & \multicolumn{3}{|c|}{ PVM atskaita / VAT } & + & + & + \\
\hline \multirow{7}{*}{ 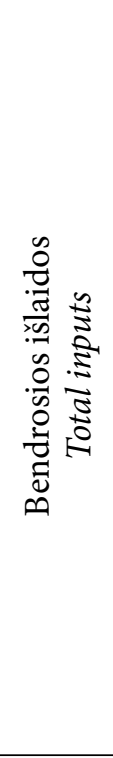 } & \multirow{2}{*}{ 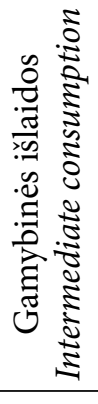 } & $\begin{array}{l}\text { Specifinès } \\
\text { išlaidos } \\
\text { Specific costs }\end{array}$ & $\begin{array}{l}\text { Sėklos, trąšos, augalų } \\
\text { apsauga, pašarai, kt. } \\
\text { Seeds, fertilizers, crop pro- } \\
\text { tection, feedstuffs, etc. }\end{array}$ & - & - & - \\
\hline & & $\begin{array}{l}\text { Pridètinès } \\
\text { išlaidos } \\
\text { Farming over- } \\
\quad \text { heads }\end{array}$ & $\begin{array}{c}\text { Mašinų ir pastatų } \\
\text { priežiūra, energija, degalai, } \\
\text { darbas pagal sutartị, kt. } \\
\text { Machinery and buildings, } \\
\text { energy, contractual work, etc. }\end{array}$ & - & - & - \\
\hline & \multicolumn{3}{|c|}{$\begin{array}{c}\text { Mokesčiai (be PVM) } \\
\text { Taxes (not VAT) }\end{array}$} & - & - & - \\
\hline & \multicolumn{3}{|c|}{ Nusidèvejjimas / Depreciation } & - & - & - \\
\hline & \multirow{3}{*}{\multicolumn{2}{|c|}{$\begin{array}{l}\text { Kitos išlaidos } \\
\text { External factors }\end{array}$}} & $\begin{array}{l}\text { Atlyginimai } \\
\text { Wages }\end{array}$ & & - & - \\
\hline & & & Nuoma / Rent & & - & - \\
\hline & & & $\begin{array}{l}\text { Palūkanos } \\
\text { Interest paid }\end{array}$ & & - & - \\
\hline \multicolumn{4}{|c|}{$\begin{array}{l}\text { Ūkininko ir jo ūkio narių neapmoketas darbas } \\
\text { Family labour cost }\end{array}$} & & & - \\
\hline \multicolumn{4}{|c|}{ Nuosava žemé / Own land cost } & & & - \\
\hline \multicolumn{4}{|c|}{$\begin{array}{l}\text { Nuosavas kapitalas } \\
\text { Own capital cost }\end{array}$} & & & - \\
\hline
\end{tabular}


ùkio narių darbo valandas iš vidutinio minimalaus valandinio atlyginimo žemès ūkyje. Metinès ūkininko ir ūkio narių darbo valandos yra ūkininkų veiklos ataskaitose, minimalus valandinis atlyginimas - LAEI leidinyje (Žemès..., 2005; Ūkių..., 2011).

2. Ükininko nuosavos žemès išlaidos nustatomos dauginant turimą nuosavą žemès ūkio naudmenų plotą iš vidutinès metinès žemès nuomos kainos, pateiktos LAEI tyrime (Žemès..., 2005a) ir ŽÜIKVC (2011) informaciniame pranešime.

3. Nuosavo kapitalo išlaidos apskaičiuojamos dauginant ūkininko ūkio kapitalo vertę be žemès (daugiamečiai sodiniai, miškas, gamybiniai pastatai, ịrenginiai ir inventorius, mašininè ịranga, augalininkystès atsargos ir gyvuliai, kvotos, kitas žemès ūkio turtas) iš penkerių metų obligacijų, denominuotų litais, realios palūkanų normos svertinio vidurkio, pateikto 2007 ir 2011 m. Lietuvos Vyriausybès vertybinių popierių metinėse apžvalgose.

Siekiant ịvertinti pajamų iš ne žemès ūkio veiklos poveiki ūkininkų ūkių gyvybingumui, nustatant 1 lentelejje pateiktų rodiklių reikšmes pridètos pajamos iš ne žemès ūkio veiklos. Teigiama arba lygi nuliui rodiklio reikšmè rodo ūkininko ūkio gyvybingumą pagal nagrinejjamą požymį.

Tyrimas vertina ūkininkų ùkių ekonominio gyvybingumo situaciją ir leidžia atskleisti jos pokytị pasirinktų ūkininkavimo tipų ùkiuose. Svarbu pažymèti, kad tyrimui naudota UADT metodika, t. y. pajamos skaičiuojamos pagal bendrosios produkcijos vertès rodikli, kuris įvertina ekonomini gamybos potencialą, bet neatsižvelgia ì ūkininkų galimybes parduoti savo produkciją.

Tyrimo ribotumą nusako ir tai, kad investicine parama yra neatsiejama nuo nusidèvejimo. ŪADT sistemoje kaupiami duomenys neleidžia išskirti paramos nusidèvejimo dalies. Gyvybingumo rodikliai buvo papildomai apskaičiuoti ir be investicinès paramos. Rezultatai atskleidè, kad $2004 \mathrm{~m}$. investicinès paramos eliminavimas beveik nekeičia gyvybingų ūkių dalies, o $2010 \mathrm{~m}$. išaugo investicinès paramos intensyvumas, todèl pastebimas nedidelis gyvybingų ūkių dalies mažèjimas.

Ūkininkų ūkių ekonominio gyvybingumo pokytis analizuojamas tiesiogiai interpretuojant gautus rezultatus ir taikant svorio koeficientų metodą (Minashkin et al., 2003). Svorio koeficientas remiasi "laisvos ekspansijos" principu, t. y. respondentinam ùkiui nustatytas svoris ekstrapoliuojamas visai grupei. Respondentinio ūkininko ūkio svoris nustatomas atsižvelgiant i 2003 ir $2010 \mathrm{~m}$. Lietuvos žemès ūkio surašymo duomenis nustatant santykị tarp respondentinių ir visų ūkių, kurie patenka $\mathfrak{i}$ tiriamų metų pasirinkto ūkininkavimo tipo ekonominio dydžio grupę. Svorio koeficientai leidžia įvertinti tiriamo ūkininko ūkio rezultato ittaką nagrinèjamo ūkininkavimo tipo ūkininkų ūkių visumai atsižvelgiant ị ūkio ekonominị dydị.

2004 ir 2010 m. rezultatai negali būti tiesiogiai lyginami tarpusavyje pagal gyvybingų ūkių dalį, kuri tenka pasirinktiems ūkio ekonominio dydžio intervalams, nes minetais metais buvo taikoma skirtinga ekonominio dydžio skaičiavimo metodika. Grafikuose pateiktas gyvybingų ūkių procentas, ivvertintas atsižvelgiant i̇ tiriamų metų ūkininkų ūkių struktūrą, ir rodo problemos mastą, todèl nagrinejjamų metų negyvybingų ùkių procentinè dalis nuo visų ūkininkavimo tipo ūkių yra palyginama.

\section{TYRIMŲ REZULTATAI IR JŲ APTARIMAS}

Analizuotų ūkininkavimo tipų ūkininkų ūkių ekonominio gyvybingumo situacija pablogejo (1 pav.). 2010 m., palyginti su 2004-aisiais, didesné dalis respondentinių ūkininkų ūkių turèjo neigiamą ŪGPV rodiklį, t. y. daugiau ūkiu nesugebejjo padengti savo gamybinių išlaidų. Labiausiai daugèjo negyvybingų augalininkystės ūkininkų ūkių $(5,5 \%)$, o mažiausiai - javų ir rapsų (1,9\%). Pajamos iš ne žemès ūkio veiklos dažnai leido padengti ūkininko ūkio nuostolius ir gerokai sumažino negyvybingų ùkių skaičių, reikšmingai pagerèjo trumpalaikio ir ilgalaikio gyvybingumo situacija pienininkystės ir augalininkystės-žolèdžių gyvulių ūkininkų ūkiuose.

BŪPS rodiklio pokytis yra panašus, tačiau dèl paramos investicijoms ir skirtingos išlaidų struktūros neigiamą rodikli turèjo mažiau respondentinių ūkių. Labiausiai daugejo negyvybingu augalininkystès-žolèdžių gyvulių ūkių (4,1\%), mažiausiai - pienininkystès ūkių (1,5\%). Pajamos iš ne žemès ūkio veiklos itin pagerino situaciją, nes didžiausias negyvybingų ūkių augimas sudarè tik 2,1 \% (augalininkystès ūkiai).

EŪPS rodiklis rodo reikšmingą ekonominio gyvybingumo pokyti. Atsiskleidè nagrinëjamų ūkininkavimo tipų ūkių ekonominio patrauklumo mažèjimas, nes ūkininkai negavo pakankamo atlyginimo už bendrąsias išlaidas ir neatlyginamų išteklių naudojimą. $2010 \mathrm{~m}$., palyginti su 


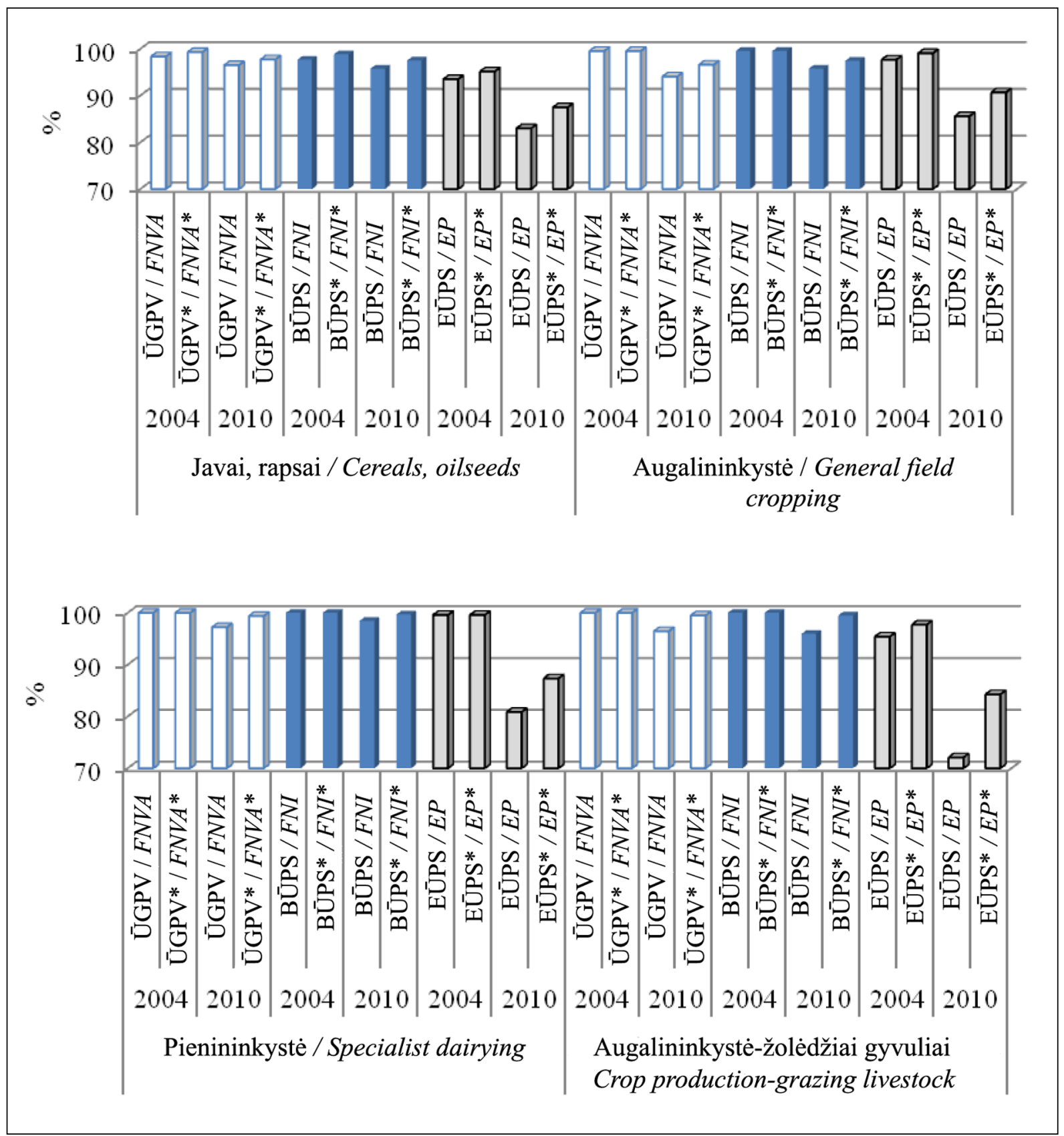

* apskaičiuojant rodikli pridedamos ne žemès ūkio veiklos pajamos / the criteria include non-farm income.

1 pav. Gyvybingi ūkiai pagal ūkininkavimo tipus, 2004 ir $2010 \mathrm{~m}$.

Fig. 1. Viable family farms by type of farming in 2004 and 2010

2004-aisiais, išaugo vidutinis valandinis atlyginimas už darbą žemès ūkyje bei žemès nuomos kaina, todèl atotrūkis tarp gyvybingų ūkininkų ūkių skaičiaus pagal BŪPS ir EŪPS rodiklius labai padidèjo. Mažiausias gyvybingų ūkininkų ūkių dalies sumažèjimas buvo javų ir rapsų ūkiuose (10,5\%), didžiausias - augalininkystės-žolèdžių gyvulių ūkiuose $(23,3 \%)$. Pajamos iš ne žemès ùkio veiklos reikšmingai sumažino negyvybingų ūkininkų ūkių dalį: svyravimo diapazonas sumažèjo nuo 7,6 \% (javų, rapsų ūkiuose) ir iki 13,4 \% (augalininkystès-žolèdžių gyvulių ūkiuose).

Tiesiogiai interpretuojant respondentinių ūkiu tyrimo rezultatus negalima vienareikšmiškai teigti, kad nagrinejjamų ūkininkavimo tipų ūkininku ūkiuose ekonominio gyvybingumo situacija pablogejo, nes respondentiniai ūkiai atstovauja ịvairioms ekonominio dydžio klasėms ir jų ịtaka 
nagrinëjamo ūkininkavimo tipo ūkininkų ūkių kytị galima îvertinti taikant svorio koeficientus visumai yra skirtinga. Tiriamo ūkininkavimo tipo (2 ir 3 pav.). Grafikai rodo, koki procentą nuo ekonomiškai negyvybingų ūkininkų ūkių po- visų nagrinèjamo ūkininkavimo tipo ūkių sudaro

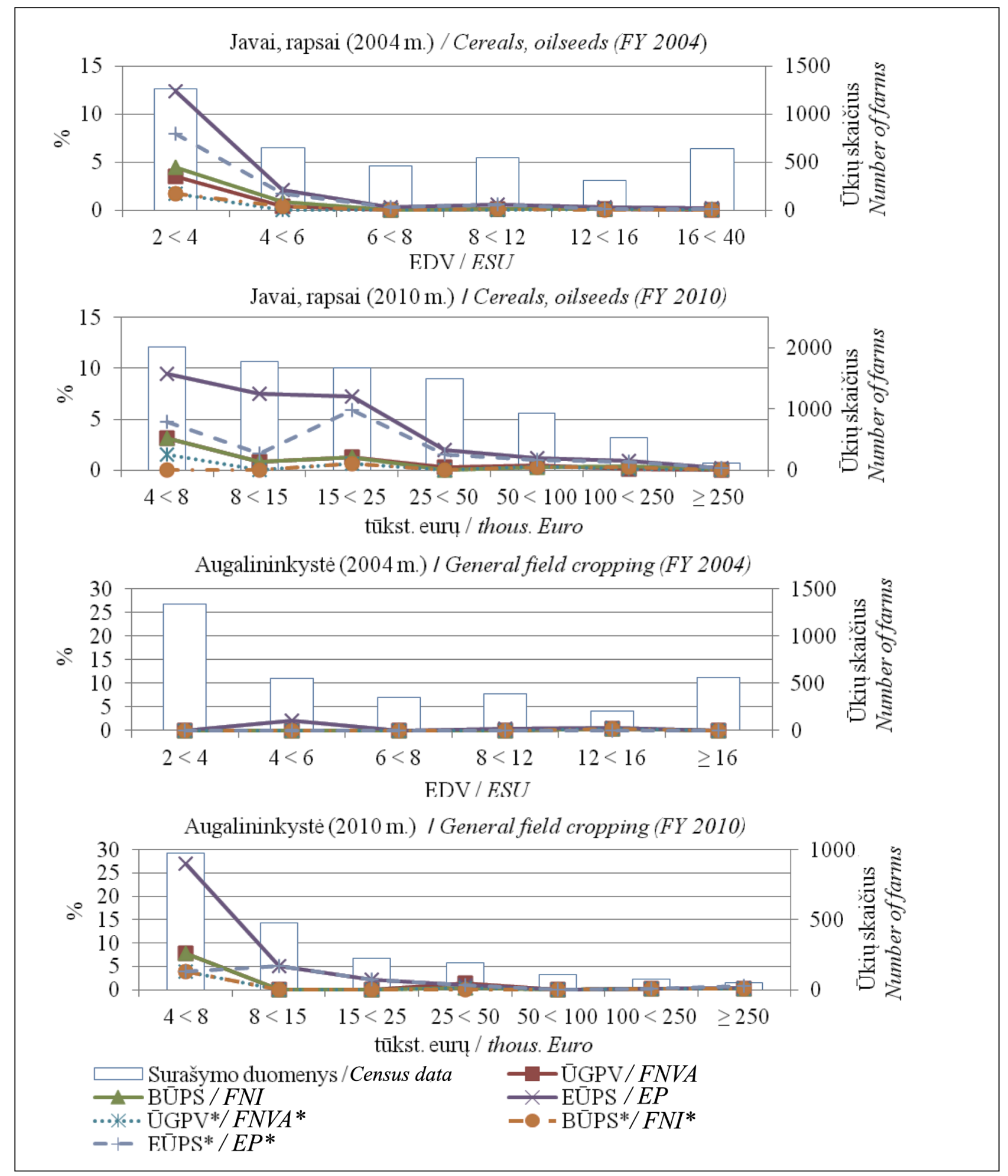

* apskaičiuojant rodiklị pridedamos ne žemès ūkio veiklos pajamos / the criteria include non-farm income.

2 pav. Negyvybingų javų, rapsų ir augalininkystès ūkininkų ùkių pokytis (rezultatai su svorio koeficientais)

Fig. 2. Change of non-viable cereals, oilseeds and general field cropping farmily farms (weighted results) 


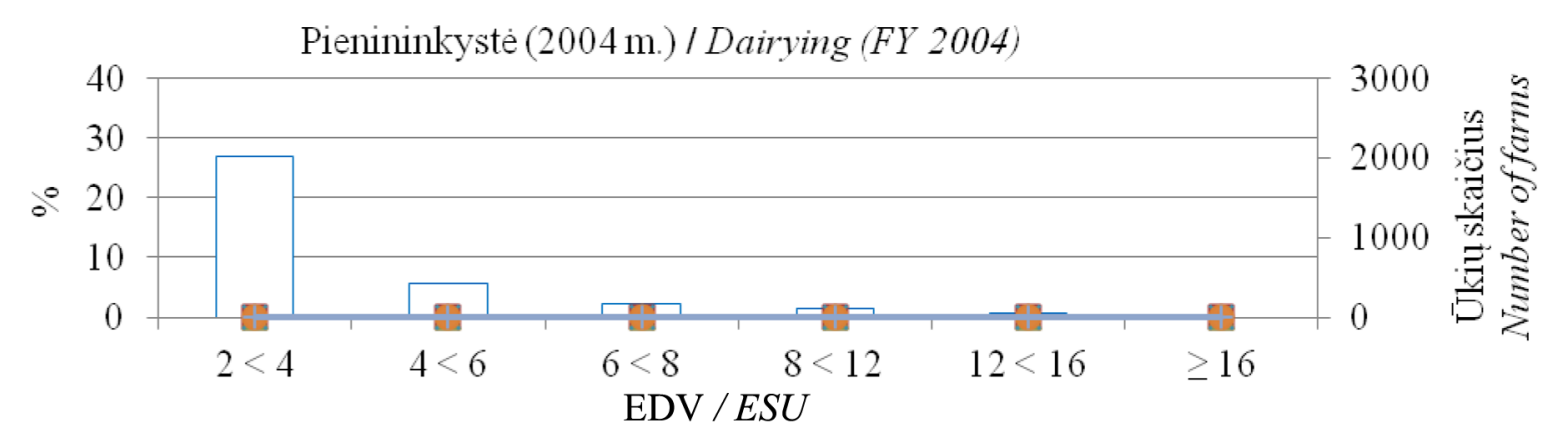

Pienininkyste (2010 m.) / Dairying (FY 2010)

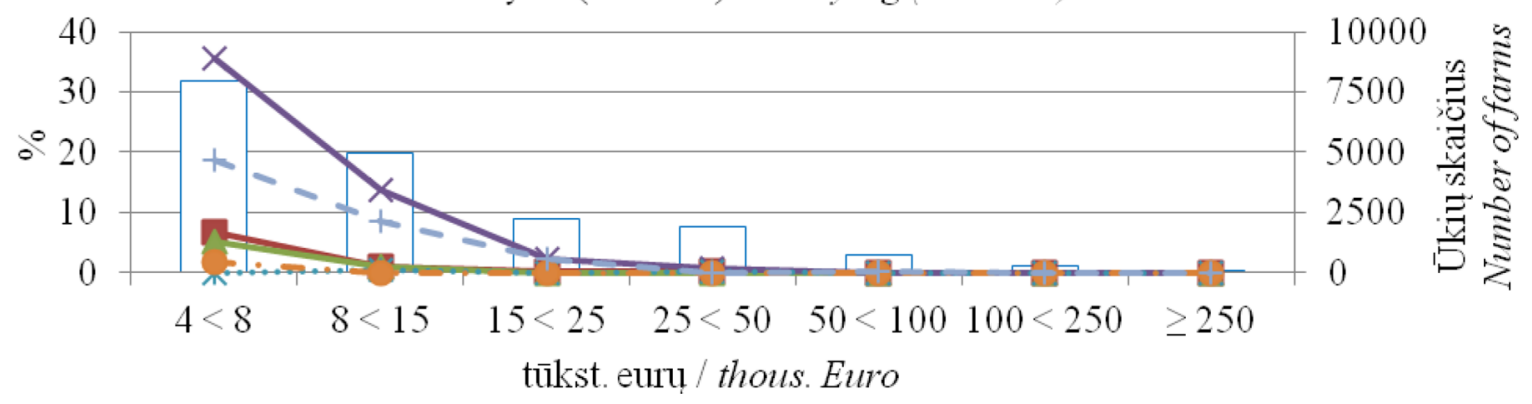

Augalininkystè-žolèdžiai gyvuliai (2004 m.)

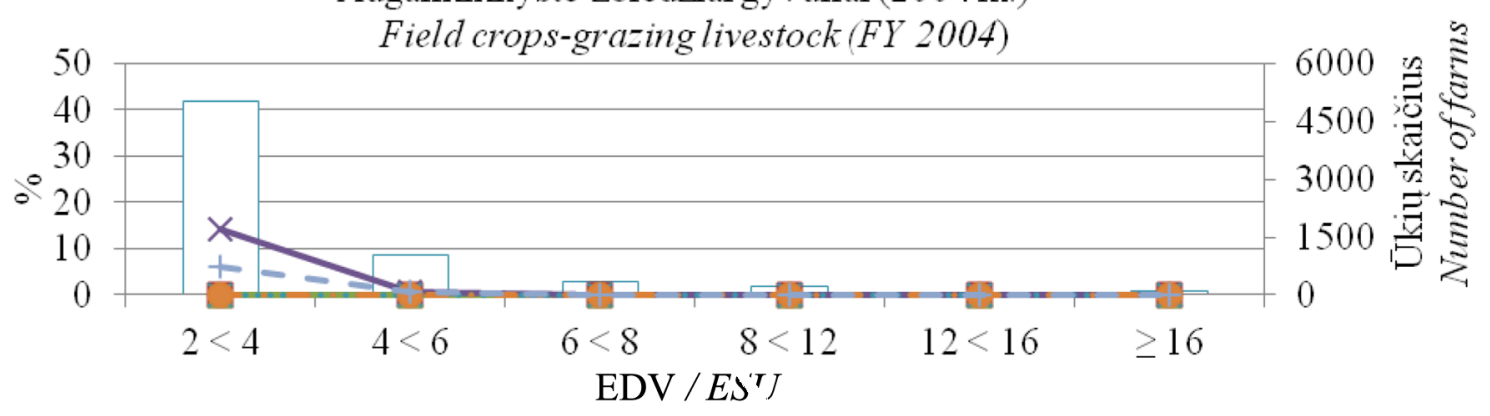

Augalininkystè-žolèdžiai gyvı.'iai (2010 m.)
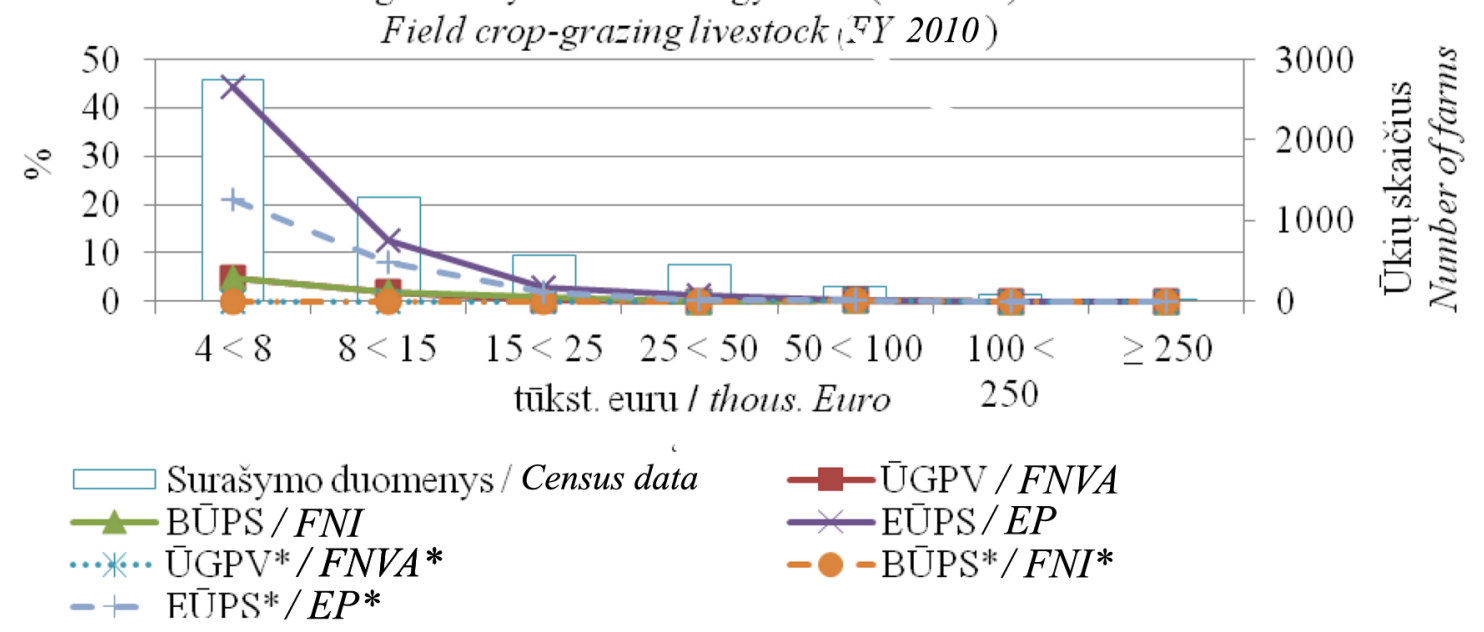

* apskaičiuojant rodikli pridedamos ne žemès ūkio veiklos pajamos / the criteria include non-farm income.

3 pav. Negyvybingų pienininkystès ir augalininkystės-žolèdžių gyvulių ūkininkų ūkių pokytis (rezultatai su svorio koeficientais)

Fig. 3. Change of non-viable dairying and field crops-grazing livestock family farms (weighted results) 
negyvybingi ūkiai pasirinktame ekonominio dydžio intervale. Visų intervalų suminè reikšmè pagal pasirinktą kriterijų rodo negyvybingų ūkių procentą visam ūkininkavimo tipui.

Lyginant ūkininkų ūkių rodiklių pokytị pritaikius svorio koeficientus, galima teigti, kad nedaug keitèsi tik negyvybingu javų ir rapsų ūkių dalis (neigiamą ŪGPV rodikli turinčių respondentų dalis padidèjo $1,9 \%$, neigiamą BÜPS - 0,4 \%, neigiamą EŪPS - 12,5 \%). Situacija labiau pasikeitè augalininkystès ir pienininkystès ūkiuose.

Vertinant situaciją pagal trumpalaikio gyvybingumo rodiklių kriterijus, daugiausia sumažèjo augalininkystės ūkių gyvybingumas (neigiamą ŪGPV rodiklį turinčių ūkių dalis padidejo 9,2\%, neigiamą BŪPS - 8,19 \%). Didžiausias negyvybingu ūkiu pokytis pagal EŪPS rodiklị ịvyko pienininkystès sektoriuje (net 52,5\% punkto).

Pajamos iš ne žemès ūkio veiklos $2010 \mathrm{~m}$. pienininkystès ir augalininkystės-žolèdžių gyvulių ūkiuose sumažino negyvybingų ūkių dali pagal $\mathrm{UGPV}^{*}$ ir BÜPS* rodiklius beveik iki $1 \%$. Augalininkystès ūkiuose situacija buvo blogiausia - negyvybingi ūkiai $2010 \mathrm{~m}$. sudarè apie $4 \%$ visu nagrinejamo tipo ūkių. Pajamų iš ne žemès ūkio veiklos svarbą ūkininkų ūkių ekonominiam gyvybingumui aiškiai rodo EŪPS rodiklis, nes $2010 \mathrm{~m}$. be pajamų iš ne žemès ūkio veiklos negyvybingų ūkininkų ūkių dalis buvo 1,8-2,8 karto didesnè.

Ūkininkų ūkių veiklos rezultatų analizė rodo, kad gyvybingų ūkių skaičius didejja jiems stambejjant. Kita įdomi tendencija - ūkiui stambejjant pajamų iš ne žemès ūkio veiklos vaidmuo ekonominiam ūkio gyvybingumui mažeja. $2010 \mathrm{~m}$. didžiausia negyvybingų ūkių dalis pateko į ekonominio dydžio intervalus, kur ūkininkai turi santykinai nedideles pajamas iš žemès ūkio ir kitos ūkinès veiklos, o iš 2 ir 3 pav. aiškiai matyti, kad didžiausias skirtumas tarp EŪPS ir EŪPS* rodiklių, nulemtas pajamų iš ne žemès ūkio veiklos, buvo kaip tik šiuose intervaluose. Vadinasi, norint išsaugoti gyvybingą žemès ūkị, svarbus kompleksinis požiūris ị Lietuvos kaimiškųjų vietovių plètrą, nes mažų ūkių gyvybingumas priklauso ne tik nuo žemès ūkio politikos, bet ir kitų politikos sričių priemonių igyvendinimo sèkmès.

ŪGPV, BŪPS ir EŪPS rodiklių trajektorijas lemia ūkininkų ūkių išlaidų ir nuosavybès struktūra (detaliau ištirti situaciją pagal ekonominio dydžio klases galima analizuojant finansinius rodiklius).
2010 m. ūkininkų ūkių gyvybingumo tendencijų palyginimas ịvairiuose ūkininkavimo tipų ūkiuose leidžia teigti, kad ekonominis gyvybingumas priklauso nuo ūkininkavimo tipo, todèl nustatant gyvybingumo slenksčius turètų būti atsižvelgta i ịvairių ūkininkavimo tipų specifiką.

\section{IŠVADOS}

Skirtingas gyvybingumo sampratos traktavimas žemès ūkyje paskatino tyrèjus vertinti ekonomini gyvybingumą remiantis ịvairiais kriterijais: pajamų (ịplaukų) ir išlaidų struktūros pokyčiu, pajamų (itplaukų) ir išlaidų santykiu, ūkio grynąja pridètine verte, pelno ir pelningumo bei finansinio stabilumo rodikliais ir kt. Tyrimas atskleide, kad mokslininkai dažniausiai pasirenka tyrimo kryptis, kurios analizuoja ekonomini gyvybingumą išskiriant trumpalaikio ir ilgalaikio reiškinio aspektus, ūkininko ūkio ir jo narių bei namų ūkio pajamų itaką. Tyrimui parinkti rodikliai leidžia įvertinti trumpalaikio ir ilgalaikio ekonominio gyvybingumo situaciją ūkininko ūkyje atsižvelgiant ì pajamų iš ne žemès ūkio veiklos poveiki gyvybingumui.

Remiantis pasirinktų ūkininkavimo tipų ūkininkų ūkių veiklos rodiklių lyginamąja analize galima teigti, kad Lietuvos ūkininkų ūkių ekonominis gyvybingumas sumažèjo, o ūkininkavimas tampa vis mažiau patraukliu verslu.

Pasirinkti analizei rodikliai parodè nevienodas pasiskirstymo pagal ekonominio dydžio klases tendencijas įvairaus ūkininkavimo tipo ūkininkų ūkiuose, todèl nustatant pažeidžiamiausių ūkių ekonominio dydžio ribą siūloma atsižvelgti i ūkininkavimo tipo specifiką. Tyrimas atskleidè, kad 2010 m. didžiausia negyvybingų ūkių dalis pateko ị intervalą iki 15-25 tūkst. eurų.

Ūkininkų ūkių ekonominio gyvybingumo tendencijų analizè (darant prielaidą, kad ùkis yra gyvybingas, jei nuostolius padengia pajamos ne iš žemès ūkio veiklos) parodè, kad šios pajamų dalies svarba ūkininko ūkio gyvybingumui mažèja, kai ūkio dydis auga. Mažų ūkininkų ūkių gyvybingumui pajamos iš ne žemès ùkio veiklos yra ypač reikšmingos, todèl siekiant išsaugoti šių ūkių gyvybingumą siūloma remtis kompleksiniu požiūriu ir derinti žemès ükio ir kitų politikos sričių priemones.

Gauta 20121120

Priimta 20130122 


\section{LITERATŪRA}

1. Agrosynergie. 2011. Evaluation of Income Effects of Direct Support. Brussels: EEIG Agrosynergie. $261 \mathrm{p}$.

2. Aubin J.-P. 1991. Viability Theory. New York: Birkhäuser Boston. 543 p.

3. Aubin J.-P., Bayen A. M., Saint-Pierre P. 2011. Viability Theory: New Directions. 2nd edition. Springer-Verlag Berlin Heidelberg. $830 \mathrm{p}$.

4. A Framework for Indicators for the Economic and Social Dimensions of Sustainable Agriculture and Rural Development. 2001. European Commission. 39 p. [žiūrèta 2012-06-10]. Prieiga per interneta: http://ec.europa.eu/agriculture/publi/reports/sustain/index_en.pdf

5. Baumgärtner S., Quaas M. F. 2009. Ecologicaleconomic viability as a criterion of strong sustainability under uncertainty. Ecological Economics. No. 68(7). P. 2008-2020.

6. Bossel H. 2001. Assessing viability and sustainability: a systems-based approach for deriving comprehensive indicator sets. Conservation Ecology. No. 5(2). P. 1-12.

7. CAST. 1988. Long-Term Viability of U. S. Agriculture: Report No. 114. Columbus: The Ohio State University. $48 \mathrm{p}$.

8. Connolly L. 2009. Changing Structure and Production Patterns of Irish Agriculture - Trends and Prospects. 17th International Farm Management Congress: Congress Proceedings. Illinois: Illinois State University. Vol. 1. P. 487-502.

9. Dillon E., Hennessy T., Hynes S., et al. 2009. Assessing the Sustainability of Irish Agriculture. P. 1-37 [žiūrèta 2012-05-18]. Prieiga per interneta: http://www.agresearch.teagasc.ie/rerc/downloads/ workingpapers/08WPRE09.pdf

10. Developments in the Income Situation of the EU Agricultural Sector. 2010. Brussels: European Union. 79 p.

11. EU Economics Overview: FADN 2007. 2010. Brussels: European Union. 59 p.

12. FADN. 2012. Annex: Standard Results Indicators. [žiūrèta 2012-05-18]. Prieiga per internetą: http:// ec.europa.eu/agriculture/rica/annex003_en.cfm

13. Foltz J. D. 2004. Entry, exit, and farm size: assessing an experiment in dairy price policy. American Journal of Agricultural Economics. No. 86(3). P. 594-604.

14. Fritzsch J., Wegener S., Buchenrieder G., et al. 2010. Economic Prospect for Semi-Subsistence Farm Households in EU New Member States. Luxembourg: Publications Office of the European Union. $326 \mathrm{p}$.

15. Glauben T., Tietje H., Weiss C. 2006. Agriculture on the move: Exploring regional differences in farm exit rates in Western Germany. Jahrbuch für Regionalwissenschaft. Vol. 26. P. 103-118.
16. Hennessy T., O'Brien M., et al. 2007. An Examination of the Contribution of Off-Farm Income to the Viability and Sustainability of Farm Households and the Productivity of Farm Businesses. 230 p. [žiūrèta 2012-06-10]. Prieiga per interneta: http://www.teagasc.ie/research/reports/ ruraldevelopment/5490/eopr-5490.pdf

17. Huck P. 2007. Viability Theory and Soil Development. 47th Annual Conference, German Association of Agricultural Economists: Conference Paper. Weihenstephan: GEWISOLA. P. 1-11. [žiūreta 2012-06-10]. Prieiga per internetą: http://ageconsearch.umn.edu/handle/7582

18. Minashkin V. G., Gusynin A. B., Sadovnikova N. A., et al. 2003. Kurs lektsiypo teorii statistiki. Moskva: MMIEIFP. 189 s.

19. Morehart M. 2000. A Fair Income for Farmers? Agricultural Outlook, AGO-271. P. 22-26 [žiūrèta 2012-05-18]. Prieiga per interneta: http://www. ers.usda.gov/publications/agoutlook/may2000/ ao271i.pdf

20. Savickienẻ J., Slavickienè A. 2012. Ūkių ekonominị gyvybingumą lemiančiu veiksnių vertinimas Lietuvos ūkininku ūkių pavyzdžiu. Žemés ūkio mokslai. Nr. 19(1). P. 53-67.

21. Scott J. 2005. Farm and Community Viability. NS: GPI Atlantic. $116 \mathrm{p}$.

22. Scott J. 2008. Nova Scotia GPI Soils and Agriculture Accounts: Part 2: Resource Capacity and Use. Section 3: Land Capacity. Measuring Sustainable Development Application of the Genuine Progress Index to Nova Scotia. NS: GPI Atlantic. $22 \mathrm{p}$.

23. Scott J., Colman R. 2008a. The GPI Soils and Agriculture Accounts: Towards a Healthy Farm and Food System: Indicators of Genuine Progress. NS: GPI Atlantic. $280 \mathrm{p}$.

24. Scott J., Colman R. 2008. The GPI Soils and Agriculture Accounts: Economic Viability of Farms and Farm Communities in Nova Scotia and Prince Edward Island - an Update. NS: GPI Atlantic. $87 \mathrm{p}$.

25. Ükiu veiklos rezultatai (ÜADT tyrimo duomenys) 2010. 2011. Vilnius: LAEI. 108 p.

26. Vrolijk H. C. J., de Bont C. J. A. M., Blokland P. W., et al. 2010. Farm Viability in the European Union. Hague: LEI. $67 \mathrm{p}$.

27. Zeddies J. 1991. Viability of Farms. Luxembourg: Office for Official Publications of the European Communities. $62 \mathrm{p}$.

28. ŽŪIKVC. 2011. Žemès ūkio paskirties žemés nuomos kainos $2010 \mathrm{~m}$. [žiürèta 2012-0705]. Prieiga per internetą: https://www.vic. It/?mid=151\&id=5979

29. Zemés ūkio paskirties žemés rinkos pokyčiu tyrimas. 2005a. Vilnius: LAEI. 66 p.

30. Žemés ükio respondentiniu ìmoniu duomenys 2004. 2005. Vilnius: LAEI. 106 p. 
Nelè Jurkènaitè

COMPARATIVE ANALYSIS OF LITHUANIAN

FAMILY FARMS' ECONOMIC VIABILITY

Sum mary

This study contributes to research of family farms' viability covering an important aspect of economic viability. The aim of the paper is to analyze economic viability change of the Lithuanian family farms specialized in cereals and oilseeds, general field cropping, dairying and field crops-grazing livestock. The analysis of scientific literature, context analysis, the synthesis of scientists' standpoints and interpretations let us to identify main directions and limitations of performed research, and set criteria for the analysis of short-term and long-term economic viability change. Economic viability of the Lithuanian family farms is evaluated and compared on the basis of operating performance in 2004 and 2010. The research results show the decline of family farms' economic viability. There is a slight growth of non-viable family farms unable to cover farming overheads and total input. However, the long run economic attractiveness of farming activity for family farms reduced significantly. The performed analysis underlines the importance of non-farm income for small family farms' survival. Research results show that economic viability of the Lithuanian family farms depends on the type of farming.

Key words: agriculture, family farms, viability 